\begin{tabular}{|c|c|c|}
\hline JURNAL & ISSN: 2502-6496 (Print) \\
\hline $\begin{array}{c}\text { Volume 1, Nomor 2, p 52-64 } \\
\text { Oktober 2017 }\end{array}$ & http://zona.pelantarpress.co.id/ \\
\hline
\end{tabular}

\title{
Analisis daya tampung beban pencemaran Sungai Kampar Kiri Kabupaten Kampar Provinsi Riau
}

\author{
Muhammad Hidayatuddin ${ }^{1}$, Usman M Tang ${ }^{2}$, Rifardi $^{2}$ \\ ${ }^{1}$ Pusat Pengendalian Pembangunan Ekoregion Sumatera Kementerian Lingkungan Hidup Dan Kehutanan. \\ ${ }^{2}$ Dosen Pascasarjana Ilmu Lingkungan Program Pascasarjana Universitas Riau.
}

\begin{abstract}
The objectives of this study are to identify the pollutant sources location, analyze pollution load and pollution load carrying capacity of BOD (Biologycal Oxygen Demand), COD (Chemical Oxygen Demand) and TSS (Total Suspended Solid) concentrations; The QUAL2Kw methods application for modeling process of the main river were divided into nine reach, where Sibayang River (kilometre 86,629) as the headwater and Mentulik village as the downstream boundaries (km 0). The water samples where selected at ten points, with five of them are located at the main river and the rest of five at the tributaries. The modeling used water quality data on pollutant sources as input and the main river water quality data as a comparison. Based on the results of the study, total pollution load of BOD are 4,83 Tons/hour and total pollution load carrying capacity of BOD are 2,65 Tons/hour, it means a pollution load carrying capacity for BOD has been exceeded for 2,18 Tons/hour. The total pollution load of COD are 8,16 Tons/hour and total pollution load carrying capacity of COD are 8,45 Tons/hour, it means a pollution load carrying capacity for $C O D$ has not been exceeded and the main river still capable to recieve the pollution load of COD for 0,29 Tons/hour. Total pollution load of TSS are 55,90 Tons/hour and total pollution load carrying capacity of TSS are 12,45 Tons/hour, it means a pollution load carrying capacity for TSS has been exceeded for 43,45 Tons/hour. Generally total pollution load carrying capacity of BOD and TSS has been exceeded, and a total pollution load carrying capacity for $C O D$ has not been exceeded, nevertheless if review is based on river reach, an excessing of BOD pollution load has been occurred at km 18 - 1 for 1, 37 Tons/hour, COD pollution load for 2, 38 Tons/hour at km 45 - 40 and TSS pollution load for 32, 54 Tons/hour in the Teso River

Keywords: The Pollution Load; Carrying Capacity; QUAL2Kw
\end{abstract}

Sungai Kampar Kiri adalah salah satu Daerah Aliran Sungai (DAS) yang berpotensi sebagai DAS kritis di Indonesia. Secara alami Sungai Kampar Kiri mengalir dari hulu ke hilir melewati berbagai daerah di sepanjang alirannya dengan berbagai aktivitas yang terdapat didalamnya. Berbagai aktivitas yang terdapat disepanjang aliran sungai termasuk Daerah Alirannya (DAS) berpotensi menimbulkan berbagai permasalahan termasuk permasalahan kuantitas dan kualitas air. Konversi (pengalihan) hutan di daerah tangkapan air menjadi penggunaan lahan perkebunan dan pertanian misalnya, secara teoritis akan menurunkan kuantitas air karena menurunnya daya simpan air baik air tanah maupun air permukaan. Disisi lain limbah industri, penggunaan pupuk untuk pertanian dan perkebunan, pakan ternak, pakan ikan di keramba, penambangan emas tanpa izin (PETI), penambangan pasir dan kerikil serta bahan galian lain di badan sungai, buangan limbah rumah tangga dan sumber-sumber pencemaran lainnya yang menyebabkan kualitas air sungai terdegradasi, terlebih lagi bila jumlah buangan tersebut melampaui ambang batas sehingga sungai kehilangan kemampuan untuk melakukan self purification.

Berbagai aktivitas tersebut juga akan mengakibatkan besarnya beban pencemaran yang masuk ke dalam sungai, sehingga DAS Kampar Kiri menjadi sangat berpotensi termasuk sebagai DAS kritis. Salah satu indikator kekritisan DAS adalah telah terjadinya pencemaran air sungai yang dapat diukur melalui besarnya beban pencemaran. Dalam konteks pencemaran air, kekritisan DAS dapat ditekan dengan menurunkan beban pencemar yang masuk ke dalam badan air. Besarnya penurunan beban pencemar ditentukan berdasarkan daya tampung lingkungan badan air terhadap beban pencemar.

Masalah yang sering muncul pada saat pengambilan keputusan dalam hal pengelolaan sumbersumber pencemar serta pengelolaan pemanfaatan lahan di sekitar sungai adalah di mana beban itu harus diturunkan, dari aktivitas apa, parameter apa dan berapa besarannya. Berdasarkan informasi tentang aktivitas di Sungai Kampar Kiri, maka parameter kunci yang digunakan dalam penelitian ini, yaitu BOD (Biochemical Oxygen Demand) untuk mendeteksi sumber pencemar pertanian, perkebunan, permukiman dan industri, COD (Chemical Oxygen Demand) untuk mendeteksi sumber pencemar industri dengan limbah nonorganik dan TSS (total suspended solid) untuk aktivitas penambangan. 
Guna perencanaan pengelolaan DAS Sungai Kampar kiri kedepan, maka perlu diketahui dan dikaji lebih mendalam besarnya beban pencemar yang masuk ke aliran sungai utama dari berbagai sumber pencemar yang terdapat di sepanjang sungai, serta seberapa besar daya tampung beban pencemaran Sungai Kampar kiri ini terhadap beban pencemarnya tersebut.

Penelitian ini bertujuan untuk: (1) menganalisis beban pencemaran dan daya tampung beban pencemaran parameter BOD, COD dan TSS di Sungai Kampar Kiri dan (2) mengidentifikasi lokasi sumber-sumber pencemar di Sungai Kampar Kiri.

\section{METODE PENELITIAN}

Hasil akhir dari penelitian ini adalah diperolehnya nilai beban pencemaran sungai dan daya tampung beban pencemaran sungai untuk parameter BOD, COD dan TSS dengan menggunakan model QUAL2Kw yang telah terkalibrasi. Hasil tersebut diperoleh dengan menggunakan kerangka pendekatan alur kerja penelitian sebagaimana disajikan pada gambar berikut

Pengukuran parameter fisika dilakukan secara insitu meliputi suhu diukur menggunakan termometer dan salinitas diukur menggunakan hand held refractometer, kecerahan diukur menggunakan secchi disc, kecepatan arus diukur menggunakan current meter. Pengukuran parameter kimia, yaitu $\mathrm{pH}$ menggunakan $\mathrm{pH}$ meter, oksigen terlarut menggunakan DO meter. Contoh air untuk penentuan konsentrasi unsur hara (nitrat, phospat, silikat) dan parameter kimia (TSS, BOD) diambil menggunakan water sampler. Analisis unsur hara dilakukan di Laboratorium Kimia Laut Fakultas Perikanan dan Ilmu Kelautan Universitas Riau sedangkan analisis TSS dan BOD dilakukan di Laboratorium Ekologi Perairan. Peralatan pendukung lainnya yang dipergunakan yaitu GPSmap Garmin 62s, kamera digital, peralatan tulis, kertas label, isolatif, cutter, buku catatan dan lain-lain. Metode penelitian yang digunakan adalah metode deskripsi dengan menyajikan hasil pengamatan dalam bentuk tabel dan grafik dan kemudian dianalisis secara deskriptif.

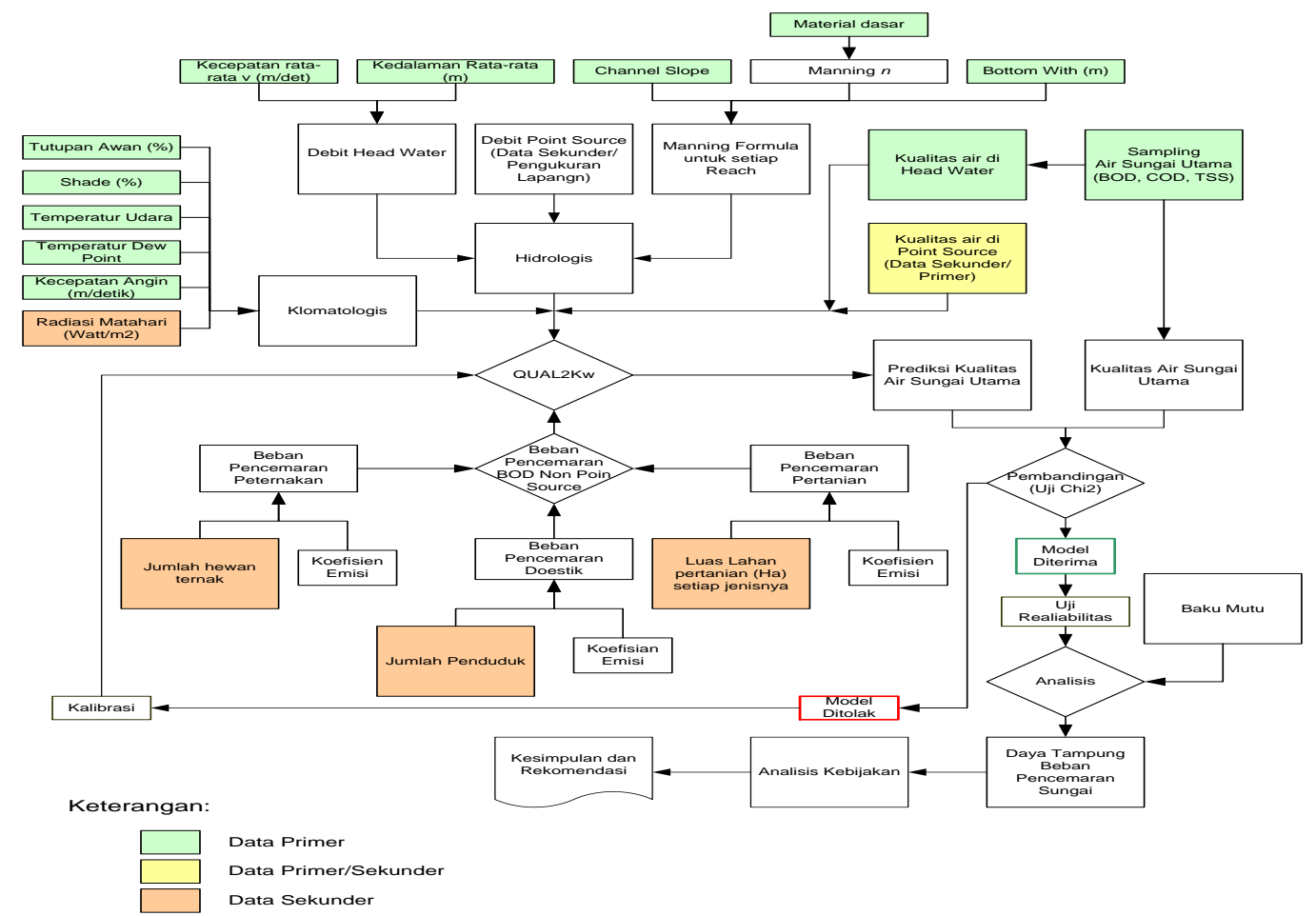

Gambar 1. Kerangka Pendekatan Alur Kerja Penelitian

Pusat dari seluruh aktivitas penelitian adalah pengujian penggunaan model QUAL2Kw untuk mengkaji daya tampung beban pencemaran sungai. Empat kelompok data utama yang dipergunakan sebagai masukan adalah data hidrologis, data klimatologis, data kualitas air sungai, serta data beban pencemaran. Data beban pencemaran dari sumber pencemar non titik (SPNT/NPS) tidak dimasukkan secara langsung dalam proses pemodelan, namun menjadi bahan pertimbangan didalam penarikan kesimpulan. Di dalam proses simulasi, beban pencemaran dari SPNT/NPS merupakan komponen yang berperan dalam memberikan ruang untuk dilakukannya proses trial and error. Berdasarkan masukan dari empat kelompok data tersebut, simulasi dilakukan hingga diperoleh model sebaran kualitas air yang paling mendekati data lapangan. Pengujian kecocokan antara data lapangan dengan data model dilakukan menggunakan uji Chi Square. Model kualitas air yang paling mendekati data lapangan dipergunakan untuk 
menghitung beban pencemaran dan daya tampung beban pencemaran sungai. Tingkat keterpercayaan hasil pemodelan diuji dengan uji reliabilitas. Uji reliabilitas tidak mempengaruhi apakah model diterima ataupun ditolak, namun memberikan tingkat keyakinan dalam penggunaan model.

Penelitian ini dilakukan di Sungai Kampar Kiri pada segmen hulu di Sungai Sebayang Desa Teluk Paman Kecamatan Kampar Kiri hingga segmen tengah di Desa Mentulik Kabupaten Kampar Provinsi Riau. Waktu pengambilan sampel kualitas air dilakukan pada musim kemarau sehingga diperoleh debit sungai yang terendah. Pemilihan segmen hulu hingga tengah didasarkan atas pertimbangan konseptual bahwa Metode QUAL2Kw tidak dapat mengakomodasi daerah hilir sungai yang dipengaruhi oleh pasang surut air laut, dimana terjadi arah aliran bolak-balik.

Sungai di dalam wilayah kajian dibagi dalam penggalan-penggalan (reach) yang berfungsi sebagai unit analisis untuk memperkirakan jumlah besaran beban pencemar pada masing-masing sumber pencemar. Oleh karena itu penentuan reach didasarkan pada perkiraan lokasi terdapatnya sumber pencemar baik berupa point source (SPT) maupun non point source (SPNT). Berdasarkan pertimbangan tersebut, sungai di wilayah kajian dibagi kedalam 9 reach. Sungai Sibayang merupakan downstream of headwater terletak pada kilometer ke 86,629 dari desa Mentulik yang merupakan downstream of last reach pada kilometer ke 0 .

Tabel 1. Pembagian reach daerah penelitian

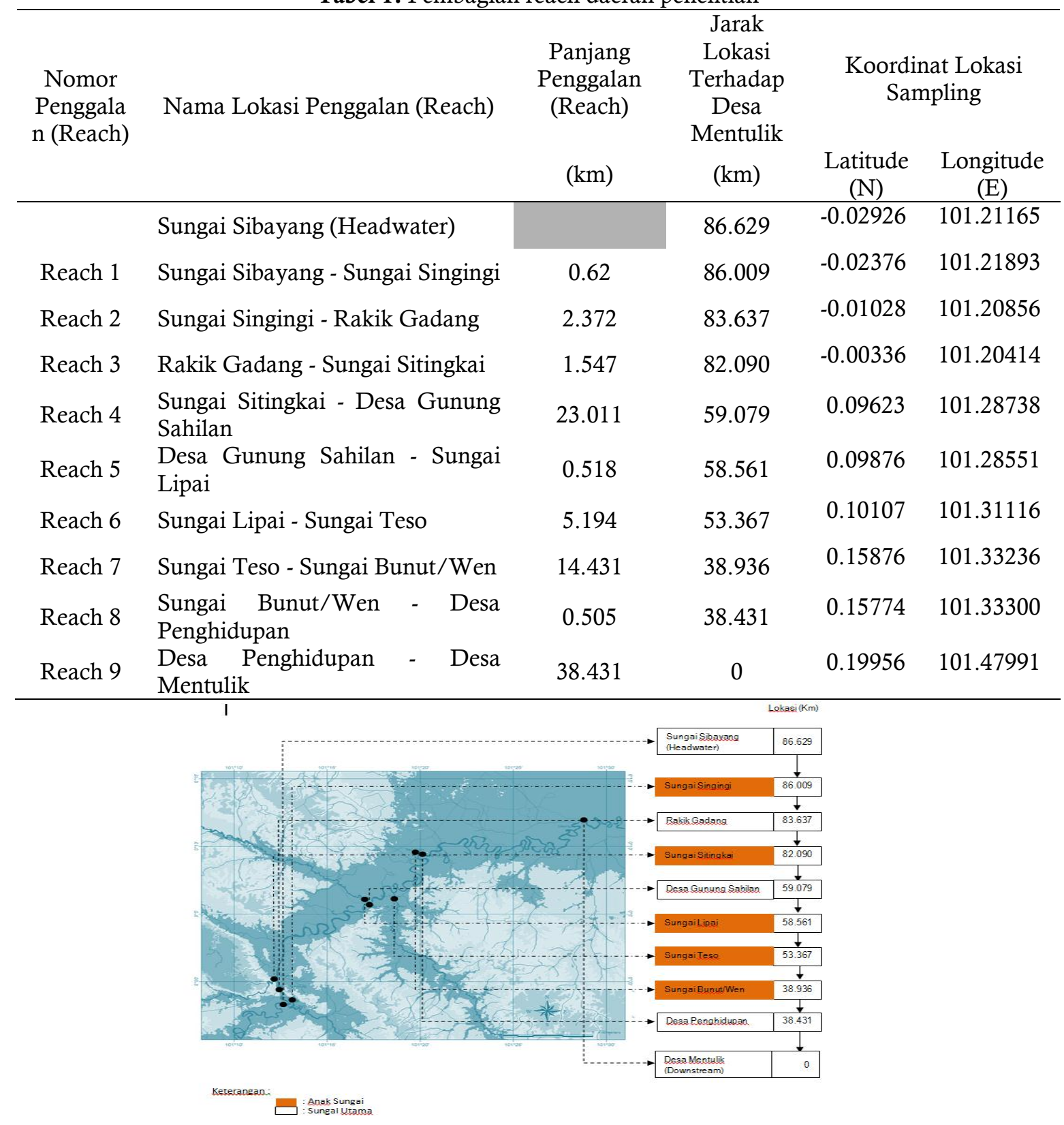

Gambar 2. Diagram Pembagian Penggal Sungai 


\section{HASIL DAN PEMBAHASAN}

\section{Kondisi Ekologis Daerah Penelitian}

Sungai Kampar Kiri berasal dari mata air gunung Ngalautinggi, gunung Solokjanjang, gunung Paninjauan nan elok, dengan Luas catchment area air sebesar $7.053 \mathrm{~km} 2$. Sungai Kampar Kiri memiliki Dua anak sungai besar bernama sungai Sibayang dan sungai Singingi. Sungai Sibayang mengalir bertemu dengan anak sungai Biobio dengan kecepatan aliran sekitar $500 \mathrm{~m} 3 /$ det. Selanjutnya bergabung dengan sungai Singingi, dan anak sungai Teso.

Tabel 2. Nilai parameter kualitas air Sungai Kampar Kiri pada kondisi debit terendah (April 2014)

\begin{tabular}{lllll}
\hline \multirow{2}{*}{ No Lokasi } & $\begin{array}{l}\text { Debit } \\
(\mathrm{m} 3 / \mathrm{dtk})\end{array}$ & \multicolumn{3}{l}{ Nilai (mg/L) } \\
\cline { 3 - 5 } & & BOD & COD & TSS \\
\hline Sungai Sibayang & 15,40 & 4,37 & 7,00 & 24,00 \\
Sungai Singingi* & 14,28 & 4,69 & 18,78 & 465,50 \\
Rakik Gadang & 39,88 & 3,52 & 10,00 & 204,00 \\
Sungai Sitingkai* & 3,70 & 4,73 & 5,89 & 36,00 \\
Desa Gunung Sahilan & 66,49 & 3,88 & 6,00 & 133,00 \\
Sungai Lipai* & 5,38 & 3,85 & 10,20 & 124,00 \\
Sungai Teso* & 19,09 & 3,12 & 21,18 & 473,50 \\
Sungai Bunut/Wen* & 0,60 & 5,33 & 11,78 & 37,00 \\
Desa Penghidupan & 67,30 & 3,63 & 13,00 & 125,00 \\
Desa Mentulik & 111,02 & 3,26 & 8,00 & 48,00 \\
\hline
\end{tabular}

* = anak sungai/ point source (PS)

Sumber: Data primer

\section{Beban Pencemaran dan Daya Tampung BOD}

\section{Beban Pencemaran BOD}

Simulasi dilakukan secara berulang-ulang (trial eror) terhadap model konsentrasi BOD untuk menghasilkan kombinasi konsentrasi dan debit pada sumber pencemar yang paling sesuai dengan sebaran konsentrasi BOD hasil observasi, sehingga dapat ditentukan beban pencemarannya. Perhitungan beban pencemaran BOD disajikan pada Tabel 3.

Tabel 3. Perhitungan Beban Pencemaran BOD

\begin{tabular}{|c|c|c|c|c|c|c|c|c|}
\hline \multirow{3}{*}{ ss } & \multicolumn{3}{|c|}{ Lokasi } & \multicolumn{2}{|c|}{ Debit } & $\mathrm{BOD}$ & \multirow{2}{*}{\multicolumn{2}{|c|}{ Beban Pencemaran BOD }} \\
\hline & \multirow{2}{*}{$\mathrm{km}$} & \multirow{2}{*}{$\begin{array}{l}\mathrm{Up} \\
\mathrm{km}\end{array}$} & \multirow{2}{*}{$\begin{array}{c}\text { Down } \\
\mathrm{km} \\
\end{array}$} & \multirow{2}{*}{$\begin{array}{c}\text { Abstraction } \\
\mathrm{m} 3 / \mathrm{s} \\
\end{array}$} & \multirow{2}{*}{$\begin{array}{c}\text { Inflow } \\
\mathrm{m} 3 / \mathrm{s}\end{array}$} & \multirow{2}{*}{$\mathrm{mgO} 2 / \mathrm{L}$} & & \\
\hline & & & & & & & Ton/Jam & $\mathrm{Kg} /$ Hari \\
\hline S. Singingi & 86,009 & & & & 14,28 & 4,69 & 0,24 & 5.786 \\
\hline S. Sitingkai & 82,09 & & & & 3,70 & 4,73 & 0,06 & 1.512 \\
\hline S. Lipai & 58,561 & & & & 5,38 & 3,85 & 0,07 & 1.790 \\
\hline S. Teso & 53,37 & & & & 19,09 & 3,12 & 0,21 & 5.146 \\
\hline S. Bunut (Wen) & 38,94 & & & & 0,60 & 5,33 & 0,01 & 276 \\
\hline NPS 1 & & 83,50 & 83,00 & & 2,00 & 7,50 & 0,05 & 1.296 \\
\hline NPS 2 & & 70,00 & 60,00 & & 2,00 & 140,00 & 1,01 & 24.192 \\
\hline NPS 3 & & 55,00 & 50,00 & & 2,00 & 50,00 & 0,36 & 8.640 \\
\hline NPS 4 & & 45,00 & 40,00 & & 2,00 & 100,00 & 0,72 & 17.280 \\
\hline NPS 5 & & 38,00 & 20,00 & & 2,00 & 100,00 & 0,72 & 17.280 \\
\hline NPS 6 & & 18,00 & 1,00 & & 2,00 & 190,00 & 1,37 & 32.832 \\
\hline Total BP BOD & & & & & & & 4,83 & 116.031 \\
\hline
\end{tabular}

Keterangan : NPS adalah sumber pencemar non titik dan

Sumber : Data primer.

Berdasarkan Tabel 3, total beban pencemaran BOD di sungai utama sebesar 4,83 Ton/jam. Jumlah tersebut berasal dari masuknya beban BOD dari sungai Singingi sebesar 0,24 Ton/jam, dari anak sungai Sitingkai 0,06 Ton/jam, dari anak sungai Lipai 0,07 Ton/jam, dari anak sungai Teso sebesar 0,21 Ton/jam, dari anak sungai Bunut (Wen) sebesar 0,1 Ton/jam. Penambahan beban juga berasal dari sumber-sumber pencemar non titik (NPS). Sumber pencemar non titik yang memberikan tambahan beban dalam jumlah besar berasal dari NPS2 pada kilometer 60 sampai kilometer 70 sebesar 1,01 Ton/jam dan NPS6 (kilometer 1 sampai 18) sebesar 1,37 Ton/jam. 


\section{Daya Tampung Beban Pencemaran BOD}

Berdasarkan Sesuai SK Gubernur Riau Nomor 23/2003 tentang Peruntukkan dan Baku Mutu Air Sungai Kampar Provinsi Riau, maka ruas Wilayah Kajian ini termasuk dalam kualitas air kelas 1 dimana batas maksimal untuk parameter BOD adalah $2 \mathrm{mg} / 1$. Dengan kondisi ini maka daya tampung sungai adalah sebesar 2,65 Ton/jam (Tabel 4), sehingga dengan kondisi seperti ini maka beban sungai telah terlampaui sebesar 2,18 Ton/jam. Proses simulasi penambahan terhadap BOD model sampai diperoleh sebaran BOD yang mendekati baku mutu (BOD bakumutu) menghasilkan kombinasi debit dan konsentrasi pada setiap sumber pencemar yang digunakan dalam perhitungan daya tampung beban pencemaran BOD (Tabel 4). Gambar 3. merupakan perbandingan antara sebaran BOD model dengan sebaran BOD bakumutu.

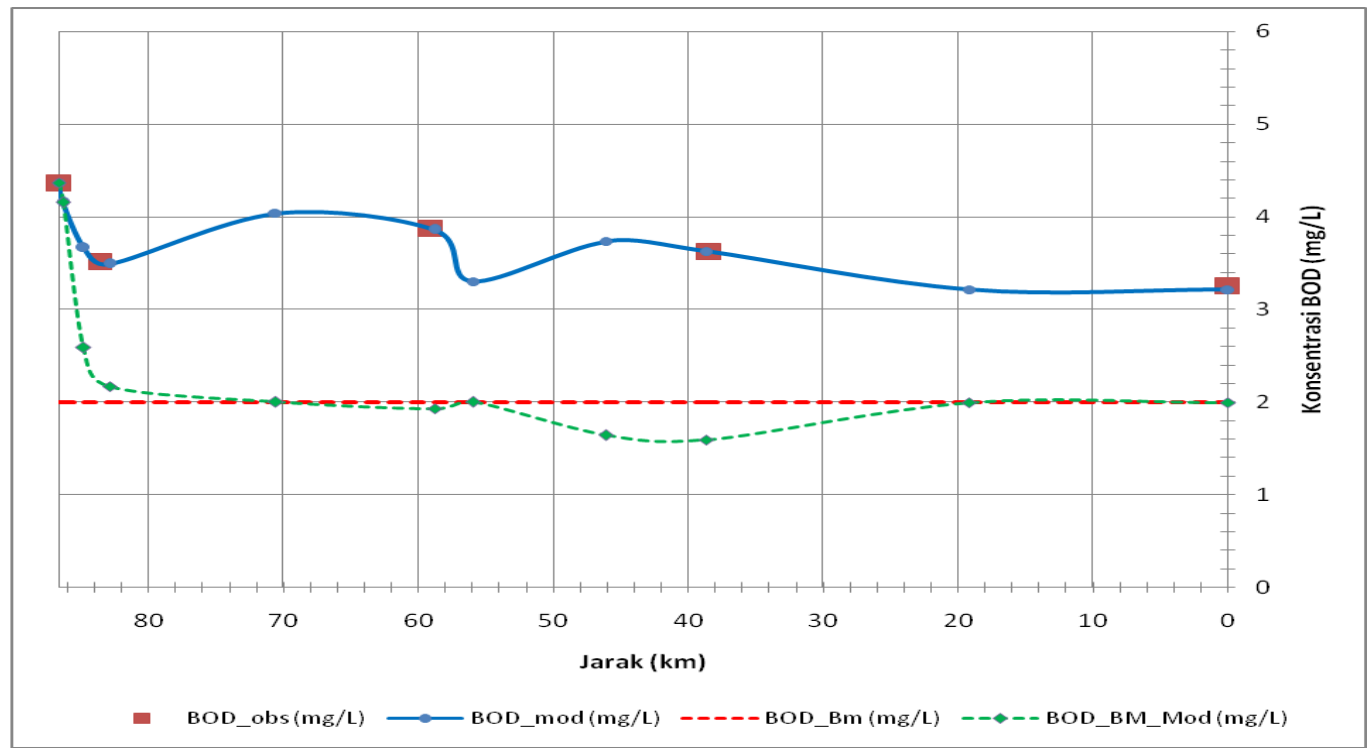

Gambar 3. Perbandingan Sebaran BOD model dengan BOD bakumutu

Tabel 4. Perhitungan Daya Tampung Beban Pencemaran BOD

\begin{tabular}{|c|c|c|c|c|c|c|c|c|}
\hline \multirow{3}{*}{ Sources } & \multicolumn{3}{|c|}{ Lokasi } & \multicolumn{2}{|c|}{ Debit } & BOD & \multirow{2}{*}{\multicolumn{2}{|c|}{ Daya Tampung BOD }} \\
\hline & \multirow{2}{*}{$\mathrm{km}$} & \multirow{2}{*}{$\begin{array}{l}\mathrm{Up} \\
\mathrm{km}\end{array}$} & \multirow{2}{*}{$\frac{\text { Down }}{\mathrm{km}}$} & \multirow{2}{*}{$\begin{array}{c}\text { Abstraction } \\
\mathrm{m} 3 / \mathrm{s}\end{array}$} & \multirow{2}{*}{$\begin{array}{c}\text { Inflow } \\
\mathrm{m} 3 / \mathrm{s}\end{array}$} & \multirow{2}{*}{$\mathrm{mgO} 2 / \mathrm{L}$} & & \\
\hline & & & & & & & Ton/Jam & $\mathrm{Kg} /$ Hari \\
\hline S. Singingi & 86,009 & & & & 14,28 & 2,00 & 0,10 & 2.468 \\
\hline S. Sitingkai & 82,09 & & & & 3,70 & 2,00 & 0,03 & 639 \\
\hline S. Lipai & 58,561 & & & & 5,38 & 2,00 & 0,04 & 930 \\
\hline S. Teso & 53,37 & & & & 19,09 & 2,00 & 0,14 & 3.299 \\
\hline S. Bunut (Wen) & 38,94 & & & & 0,60 & 2,00 & 0,00 & 104 \\
\hline NPS 1 & & 83,50 & 83,00 & & 2,00 & 0,00 & 0,00 & - \\
\hline NPS 2 & & 70,00 & 60,00 & & 2,00 & 63,00 & 0,45 & 10.886 \\
\hline NPS 3 & & 55,00 & 50,00 & & 2,00 & 57,50 & 0,41 & 9.936 \\
\hline NPS 4 & & 45,00 & 40,00 & & 2,00 & 2,00 & 0,01 & 346 \\
\hline NPS 5 & & 38,00 & 20,00 & & 2,00 & 100,00 & 0,72 & 17.280 \\
\hline NPS 6 & & 18,00 & 1,00 & & 2,00 & 102,00 & 0,73 & 17.626 \\
\hline Total DT BOD & & & & & & & 2,65 & 63.513 \\
\hline
\end{tabular}

Keterangan: $\quad$ NPS adalah sumber pencemar non titik dan

Sumber: Data primer.

Berdasarkan Tabel 4, total daya tampung beban pencemaran BOD sebesar 2,65 Ton/jam sementara total beban pencemaran BOD pada sungai utama sebesar $4,83 \mathrm{Ton} / \mathrm{jam}$. Ini berarti bahwa, beban pencemaran untuk parameter BOD telah terlampaui sebesar 2,18 Ton/jam. Hasil ini sebagian besar kemungkinan berasal dari limbah domestik, dimana pola kebiasaan penduduk yang bermukim disekitar sungai yang menjadikan sungai sebagai sarana untuk mandi, mencuci dan buang hajat (MCK), tempat membuang sampah padat atau limbah cair dari rumah tangga, rumah makan dan serta ditambah juga dengan sisa bahan makanan ikan dan ternak dari kegiatan keramba ikan dan peternakan masyarakat yang berupa bahan-bahan organik, dan bila terurai dalam air akan menyebabkan peningkatan bahan pencemar BOD. Besarnya beban pencemar BOD ini juga dapat dihasilkan dari penggunaan pupuk pada perkebunan sawit dan perkebunan karet masyarakat serta dari limbah cair pabrik kelapa sawit yang juga banyak terdapat di sekitar kecamatan Kampar Kiri yang limbahnya secara langsung ataupun melalui sungai kecil 
atau kanal-kanal dialirkan ke Sungai Kampar kiri.

Berdasarkan perhitungan beban pencemaran dan daya tampung beban pencemaran, maka identifikasi lokasi sumber pencemar dan pengelolaan sumber-sumber pencemar dapat disusun. Tabel 5 merupakan rangkuman lokasi sumber pencemar dan proporsi beban pencemar BOD yang perlu dikelola.

Tabel 5. Pengelolaan Sumber Pencemar BOD

\begin{tabular}{llllll}
\hline Sumber & Lokasi & BOD & & Selisih & Keterangan \\
\cline { 2 - 4 } Pencemar & $(\mathrm{Km})$ & DT & BP & Ton/jam & \\
S. Singingi & 86,009 & 0,10 & 0,24 & $-0,14$ & Beban harus dikurangi $58,33 \%$ \\
S. Sitingkai & 82,09 & 0,03 & 0,06 & $-0,04$ & Beban harus dikurangi $50,00 \%$ \\
S. Lipai & 58,561 & 0,04 & 0,07 & $-0,04$ & Beban harus dikurangi $42,86 \%$ \\
S. Teso & 53,37 & 0,14 & 0,21 & $-0,08$ & Beban harus dikurangi 33,33\% \\
S. Bunut /Wen & 38,94 & 0,00 & 0,01 & $-0,01$ & Beban harus dikurangi 100,00\% \\
NPS 1 & $83,50-83,00$ & 0,00 & 0,05 & $-0,05$ & Beban harus dikurangi 100,00\% \\
NPS 2 & $70,00-60,00$ & 0,45 & 1,01 & $-0,55$ & Beban harus dikurangi 55,45\% \\
NPS 3 & $55,00-50,00$ & 0,41 & 0,36 & 0,05 & Dapat menerima beban 13,89\% \\
NPS 4 & $45,00-40,00$ & 0,01 & 0,72 & $-0,71$ & Beban harus dikurangi $98,61 \%$ \\
NPS 5 & $38,00-20,00$ & 0,72 & 0,72 & 0,00 & Beban harus dikurangi 0,00\% \\
NPS 6 & $18,00-1,00$ & 0,73 & 1,37 & $-0,63$ & Beban harus dikurangi $46,72 \%$ \\
& & 2,65 & 4,83 & $-2,18$ & Beban harus dikurangi $45,13 \%$ \\
\hline
\end{tabular}

Keterangan: DT adalah daya tampung beban pencemaran,

$\mathrm{BP}$ adalah beban pencemaran dan

NPS adalah sumber pencemar non titik.

Sumber: Data rimer.

Berdasarkan Tabel 5 diatas, Total beban pencemaran BOD di sungai utama di daerah penelitian sebesar 4,83 Ton/jam dan total daya tampung beban pencemaran BOD sebesar 2,65 Ton/jam. Itu berarti daya tampung beban pencemaran BOD pada sungai utama sudah terlampaui dan beban pencemaran BOD harus dikurangi sebesar 2,18 Ton/jam atau sebesar 45,13\%. Untuk mengurangi kelebihan beban BOD, dapat disusun beberapa alternatif yang umum digunakan dalam pengelolaan lingkungan, misalnya dengan mengidentifikasi lebih lanjut sumber-sumber pencemar yang terdapat di anak sungai tersebut, meningkatkan kinerja pengelolaan limbah, memperketat pengawasan, pengurangan produksi, penegakan hukum hingga penutupan kegiatan, tergantung pada hasil identifikasi yang dilakukan.

\section{Beban Pencemaran dan Daya Tampung COD}

\section{Beban Pencemaran COD}

Dengan cara yang sama seperti yang dilakukan pada pemodelan BOD, sehingga dapat ditentukan beban pencemarannya.

Tabel 6. Perhitungan Beban Pencemaran COD

\begin{tabular}{|c|c|c|c|c|c|c|c|c|}
\hline \multirow{3}{*}{ Sources } & \multicolumn{3}{|c|}{ Lokasi } & \multicolumn{2}{|c|}{ Debit } & COD & \multirow{2}{*}{\multicolumn{2}{|c|}{ Beban Pencemaran COD }} \\
\hline & \multirow{2}{*}{$\mathrm{km}$} & \multirow{2}{*}{$\frac{\mathrm{Up}}{\mathrm{km}}$} & \multirow{2}{*}{$\frac{\text { Down }}{\mathrm{km}}$} & \multirow{2}{*}{$\frac{\text { Abstraction }}{\mathrm{m} 3 / \mathrm{s}}$} & \multirow{2}{*}{$\frac{\text { Inflow }}{\mathrm{m} 3 / \mathrm{s}}$} & \multirow{2}{*}{$\mathrm{mg} / \mathrm{L}$} & & \\
\hline & & & & & & & Ton/Jam & $\mathrm{Kg} /$ Hari \\
\hline S. Singingi & 86,009 & & & & 14,28 & 18,78 & 0,97 & 23.171 \\
\hline S. Sitingkai & 82,09 & & & & 3,70 & 5,89 & 0,08 & 1.883 \\
\hline S. Lipai & 58,561 & & & & 5,38 & 10,20 & 0,20 & 4.741 \\
\hline S. Teso & 53,37 & & & & 19,09 & 21,18 & 1,46 & 34.934 \\
\hline S. Bunut (Wen) & 38,94 & & & & 0,60 & 11,78 & 0,03 & 611 \\
\hline NPS 1 & & 83,50 & 83,00 & & 2,00 & 0,00 & 0,00 & - \\
\hline NPS 2 & & 70,00 & 60,00 & & 2,00 & 95,00 & 0,68 & 16.416 \\
\hline NPS 3 & & 55,00 & 50,00 & & 2,00 & 0,00 & 0,00 & - \\
\hline NPS 4 & & 45,00 & 40,00 & & 2,00 & 330,00 & 2,38 & 57.024 \\
\hline NPS 5 & & 38,00 & 20,00 & & 2,00 & 0,00 & 0,00 & - \\
\hline NPS 6 & & 18,00 & 1,00 & & 2,00 & 330,00 & 2,38 & 57.024 \\
\hline Total BP COD & & & & & & & 8,16 & 195.803 \\
\hline
\end{tabular}

Keterangan: $\quad$ NPS adalah sumber pencemar non titik dan

Sumber: Data primer.

$\mathrm{BP}$ adalah beban pencemaran.

Total beban pencemaran COD di penggal sungai yang diteliti sebesar 8,16 Ton/jam. Dari sumber pencemar titik, Sungai Teso memberikan kontribusi beban pencemar COD terbesar yaitu 1,46 Ton/jam, 
selanjutnya Sungai Singingi memberikan kontribusi beban pencemar sebesar 0,97 Ton/jam, Sungai Sitingkai menambah 0,08 Ton/jam, Sungai Lipai 0,20 Ton/jam, serta sungai Bunut (Wen) sebesar 0,03 Ton/jam. Sumber pencemar non titik yang memberikan tambahan beban berturut-turut berasal dari lokasi NPS2 pada kilometer 60 hingga 70 yaitu sebesar 0,68 Ton/jam, NPS4 pada kilometer 40 hingga 45 sebesar 2,38 Ton/jam dan NPS6 pada kilometer 1 hingga 18 sebesar 2,38 Ton/jam.

\section{Daya Tampung Beban Pencemaran COD}

Baku mutu parameter COD untuk air kelas I adalah $10 \mathrm{mg} / \mathrm{L}$. Gambar 4 adalah grafik perbandingan sebaran konsentrasi CODmodel dengan CODbakumutu. Tabel 7 menyajikan perhitungan daya tampung beban pencemaran COD.

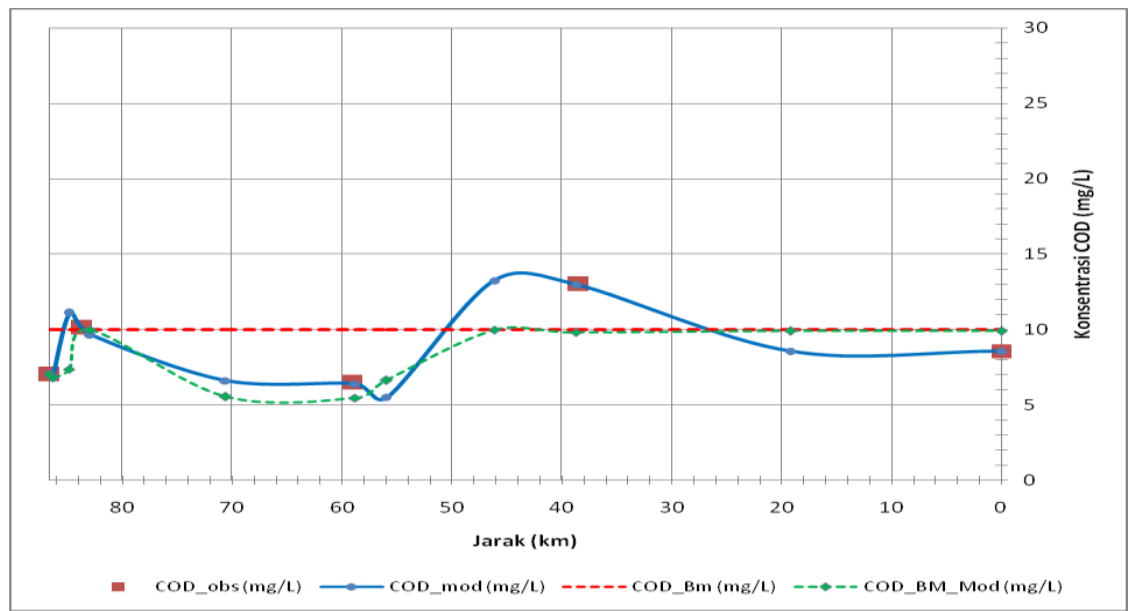

Gambar 4. Perbandingan Sebaran CODmodel dengan CODbakumutu

Berdasarkan Tabel 7, total daya tampung beban pencemaran COD sebesar 8,45 Ton/jam dengan daya tampung terbesar berada pada NPS6 (3,26 Ton/jam) diikuti NPS3 (1,1 Ton/jam) dan NPS4 (1,08 Ton/jam). Pada sumber pencemar titik, Sungai Singingi memiliki daya tampung beban pencemaran COD sebesar 0,51 Ton/jam, Sungai Sitingkai sebesar 0,13 Ton/jam, Sungai Lipai sebesar 0,19 Ton/jam, Sungai Teso sebesar 0,69 dan Sungai Bunut (Wen) sebesar 0,02 Ton/jam.

Tabel 7. Perhitungan Daya Tampung Beban Pencemaran COD

\begin{tabular}{|c|c|c|c|c|c|c|c|c|}
\hline \multirow{3}{*}{ Sources } & \multicolumn{3}{|c|}{ Lokasi } & \multicolumn{2}{|c|}{ Debit } & COD & \multirow{2}{*}{\multicolumn{2}{|c|}{ Daya Tampung COD }} \\
\hline & \multirow{2}{*}{$\mathrm{km}$} & Up & Down & Abstraction & Inflow & \multirow{2}{*}{$\mathrm{mg} / \mathrm{L}$} & & \\
\hline & & $\mathrm{km}$ & $\mathrm{km}$ & $\mathrm{m} 3 / \mathrm{s}$ & $\mathrm{m} 3 / \mathrm{s}$ & & Ton/Jam & $\mathrm{Kg} /$ Hari \\
\hline S. Singingi & 86,009 & & & & 14,28 & 10,00 & 0,51 & 12.338 \\
\hline S. Sitingkai & 82,09 & & & & 3,70 & 10,00 & 0,13 & 3.197 \\
\hline S. Lipai & 58,561 & & & & 5,38 & 10,00 & 0,19 & 4.648 \\
\hline S. Teso & 53,37 & & & & 19,09 & 10,00 & 0,69 & 16.494 \\
\hline S. Bunut (Wen) & 38,94 & & & & 0,60 & 10,00 & 0,02 & 518 \\
\hline NPS 1 & & 83,50 & 83,00 & & 2,00 & 61,30 & 0,44 & 10.593 \\
\hline NPS 2 & & 70,00 & 60,00 & & 2,00 & 41,00 & 0,30 & 7.085 \\
\hline NPS 3 & & 55,00 & 50,00 & & 2,00 & 152,50 & 1,10 & 26.352 \\
\hline NPS 4 & & 45,00 & 40,00 & & 2,00 & 150,00 & 1,08 & 25.920 \\
\hline NPS 5 & & 38,00 & 20,00 & & 2,00 & 100,00 & 0,72 & 17.280 \\
\hline NPS 6 & & 18,00 & 1,00 & & 2,00 & 453,00 & 3,26 & 78.278 \\
\hline Total DT COD & & & & & & & 8,45 & 202.703 \\
\hline
\end{tabular}

Keterangan: $\quad$ NPS adalah sumber pencemar non titik dan

DT adalah Daya Tampung beban pencemaran.

Sumber: Data primer.

Berdasarkan Tabel 7 di atas, total daya tampung beban pencemaran COD sebesar 8,45 Ton/jam, dimana angka tersebut masih lebih besar dari total beban pencemaran COD pada sungai utama yaitu sebesar $8,16 \mathrm{Ton} / \mathrm{jam}$. Ini berarti bahwa, daya tampung beban pencemaran untuk parameter COD pada sungai ini belum terlampaui dan masih dapat menerima beban pencemaran sebesar 0,29 Ton/jam. 
Kondisi beban pencemar COD ini sangat berbeda bila dibandingkan kondisi beban pencemar BOD yang sudah melampaui baku mutu. Hal ini kemungkinan besar terjadi disebabkan adanya penurunan konsentrasi COD (0,00 Ton/jam) pada beberapa penggal sungai yaitu pada kilometer 83 hingga kilometer 83,5 (NPS1 yaitu sekitar desa Rakik Gadang sampai sungai Sitingkai, sekitar kilometer 50 sampai kilometer 55 (NPS3 yaitu sesudah sungai Teso hingga sebelum sungai Bunut) serta pada NPS5 yaitu dari sesudah desa Penghidupan hingga mendekati desa Mentulik (kilometer 20 - 38). Penurunan konsentrasi COD ini di mungkinkan terjadi akibat adanya oleh proses self purification dengan adanya pengenceran karena masuknya debit air yang cukup bersih dengan konsentrasi COD yang relatif kecil dari Rakik Gadang, anak sungai Sitingkai, desa gunung sahilan dan desa penghidupan.

Tabel 8. Pengelolaan Sumber Pencemar COD

\begin{tabular}{|c|c|c|c|c|c|}
\hline \multirow{2}{*}{$\begin{array}{c}\text { Sumber } \\
\text { Pencemar }\end{array}$} & \multirow{2}{*}{$\frac{\text { Lokasi }}{(\mathrm{Km})}$} & \multicolumn{2}{|c|}{ COD } & \multirow{2}{*}{$\begin{array}{l}\text { Selisih } \\
\text { Ton/jam }\end{array}$} & \multirow[t]{2}{*}{ Keterangan } \\
\hline & & $\mathrm{DT}$ & $\mathrm{BP}$ & & \\
\hline S. Singingi & 86,009 & 0,51 & 0,97 & $-0,46$ & Beban harus dikurangi $47,42 \%$ \\
\hline S. Sitingkai & 82,09 & 0,13 & 0,08 & 0,05 & $\begin{array}{l}\text { Dapat menerima } \\
62,50 \%\end{array}$ \\
\hline S. Lipai & 58,561 & 0,19 & 0,20 & $-0,01$ & Beban harus dikurangi 5,00\% \\
\hline S. Teso & 53,37 & 0,69 & 1,46 & $-0,77$ & Beban harus dikurangi 52,74\% \\
\hline S. & 38,94 & 0,02 & 0,03 & $-0,01$ & Beban harus dikurangi $33,33 \%$ \\
\hline \multicolumn{6}{|l|}{ Bunut/Wen } \\
\hline NPS 1 & $83,50-83,00$ & 0,44 & 0,00 & 0,44 & Dapat menerima beban $100 \%$ \\
\hline NPS 2 & $70,00-60,00$ & 0,30 & 0,68 & $-0,38$ & Beban harus dikurangi $55,88 \%$ \\
\hline NPS 3 & $55,00-50,00$ & 1,10 & 0,00 & 1,10 & Dapat menerima beban $100 \%$ \\
\hline NPS 4 & $45,00-40,00$ & 1,08 & 2,38 & $-1,30$ & Beban harus dikurangi $54,62 \%$ \\
\hline NPS 5 & $38,00-20,00$ & 0,72 & 0,00 & 0,72 & Dapat menerima beban $100 \%$ \\
\hline \multirow[t]{2}{*}{ NPS 6} & $18,00-1,00$ & 3,26 & 2,38 & 0,88 & $\begin{array}{l}\text { Dapat menerima beban } \\
36,97 \%\end{array}$ \\
\hline & & 8,45 & 8,16 & 0,29 & Dapat menerima beban $3,55 \%$ \\
\hline
\end{tabular}

Keterangan: $\quad$ NPS adalah sumber pencemar non titik, BP adalah beban pencemaran

Sumber: Data primer.

DT adalah Daya Tampung beban pencemaran.

Anak Sungai Singingi, anak Sungai Lipai, anak Sungai Teso dan anak Sungai Bunut (Wen) merupakan sumber pencemar titik yang telah jenuh sehingga tidak dapat menerima tambahan beban COD. NPS2 dan NPS4 merupakan wilayah-wilayah penggal sungai yang juga tidak dapat menerima tambahan beban COD. Penambahan beban COD masih dimungkinkan dari Sungai Sitingkai sebesar 0,05 Ton/jam, NPS1 sebesar 0,44 Ton/jam, NPS3 sebesar 1,10 Ton/jam, NPS5 sebesar 0, 72 Ton/jam, dan NPS6 sebesar 0,88 Ton/jam.

\section{Beban Pencemaran dan Daya Tampung TS}

\section{Beban Pencemaran TSS}

Dengan cara yang sama seperti yang dilakukan pada pemodelan sebelumnya, sehingga dapat ditentukan beban pencemarannya. Berdasarkan Tabel 9, total beban pencemaran TSS di daerah penelitian sebesar 55,90 Ton/jam. Beban pencemaran TSS terbesar dari sumber pencemar titik berasal dari Sungai Teso yaitu sebesar 32,54 Ton/jam, selanjutnya berturut-turut dari Sungai Singingi sebesar 23,93 Ton/jam, Sungai Lipai sebesar 2,40 Ton/jam, Sungai Sitingkai sebesar 0,48 Ton/jam dan dari Sungai Bunut (Wen) sebesar 0,08 Ton/jam. 
Tabel 9. Perhitungan Beban Pencemaran TS

\begin{tabular}{|c|c|c|c|c|c|c|c|c|}
\hline \multirow{3}{*}{ Sources } & \multicolumn{3}{|c|}{ Lokasi } & \multicolumn{2}{|c|}{ Debit } & TSS & \multirow{2}{*}{\multicolumn{2}{|c|}{ Beban Pencemaran TSS }} \\
\hline & \multirow{2}{*}{$\mathrm{km}$} & \multirow{2}{*}{$\begin{array}{l}\mathrm{Up} \\
\mathrm{km}\end{array}$} & \multirow{2}{*}{$\begin{array}{c}\text { Down } \\
\mathrm{km}\end{array}$} & \multirow{2}{*}{$\begin{array}{c}\text { Abstraction } \\
\mathrm{m} 3 / \mathrm{s}\end{array}$} & \multirow{2}{*}{$\begin{array}{c}\text { Inflow } \\
\mathrm{m} 3 / \mathrm{s}\end{array}$} & \multirow{2}{*}{$\mathrm{mg} / \mathrm{L}$} & & \\
\hline & & & & & & & Ton/Jam & Kg/Hari \\
\hline S. Singingi & 86,009 & & & & 14,28 & 465,50 & 23,93 & 574.330 \\
\hline S. Sitingkai & 82,09 & & & & 3,70 & 36,00 & 0,48 & 11.508 \\
\hline S. Lipai & 58,561 & & & & 5,38 & 124,00 & 2,40 & 57.639 \\
\hline S. Teso & 53,37 & & & & 19,09 & 473,50 & 32,54 & 780.980 \\
\hline S. Bunut (Wen) & 38,94 & & & & 0,60 & 37,00 & 0,08 & 1.918 \\
\hline NPS 1 & & 83,50 & 83,00 & & 2,00 & $-275,00$ & $-1,98$ & $(47.520)$ \\
\hline NPS 2 & & 70,00 & 60,00 & & 2,00 & $-200,00$ & $-1,44$ & $(34.560)$ \\
\hline NPS 3 & & 55,00 & 50,00 & & 2,00 & $-50,00$ & $-0,36$ & $(8.640)$ \\
\hline NPS 4 & & 45,00 & 40,00 & & 2,00 & 10,00 & 0,07 & 1.728 \\
\hline NPS 5 & & 38,00 & 20,00 & & 2,00 & 15,00 & 0,11 & 2.592 \\
\hline NPS 6 & & 18,00 & 1,00 & & 2,00 & 10,00 & 0,07 & 1.728 \\
\hline Total BP TSS & & & & & & & 55,90 & 1.341 .703 \\
\hline
\end{tabular}

Keterangan: $\quad$ NPS adalah sumber pencemar non titik dan BP adalah beban pencemaran.

Sumber: Data primer.

Sumber pencemar non titik yang memberikan tambahan beban berturut-turut berasal dari lokasi NPS4 pada kilometer 40 hingga 45 yaitu sebesar 0,07 Ton/jam, NPS5 pada kilometer 20 hingga 38 sebesar 0,11 Ton/jam dan NPS6 pada kilometer 1 hingga 18 sebesar 0,07 Ton/jam.

\section{Daya Tampung Beban Pencemaran TSS}

Daya tampung beban pencemaran TSS mengacu pada baku mutu air kelas I dimana konsentrasi TSS maksimum ditetapkan sebesar $50 \mathrm{mg} / \mathrm{L}$. Hasil simulasi konsentrasi TSS yang sesuai dengan baku mutu air kelas I (TSSbaku mutu) dan perbandingannya dengan konsentrasi TSSmodel disajikan pada Gambar 5.

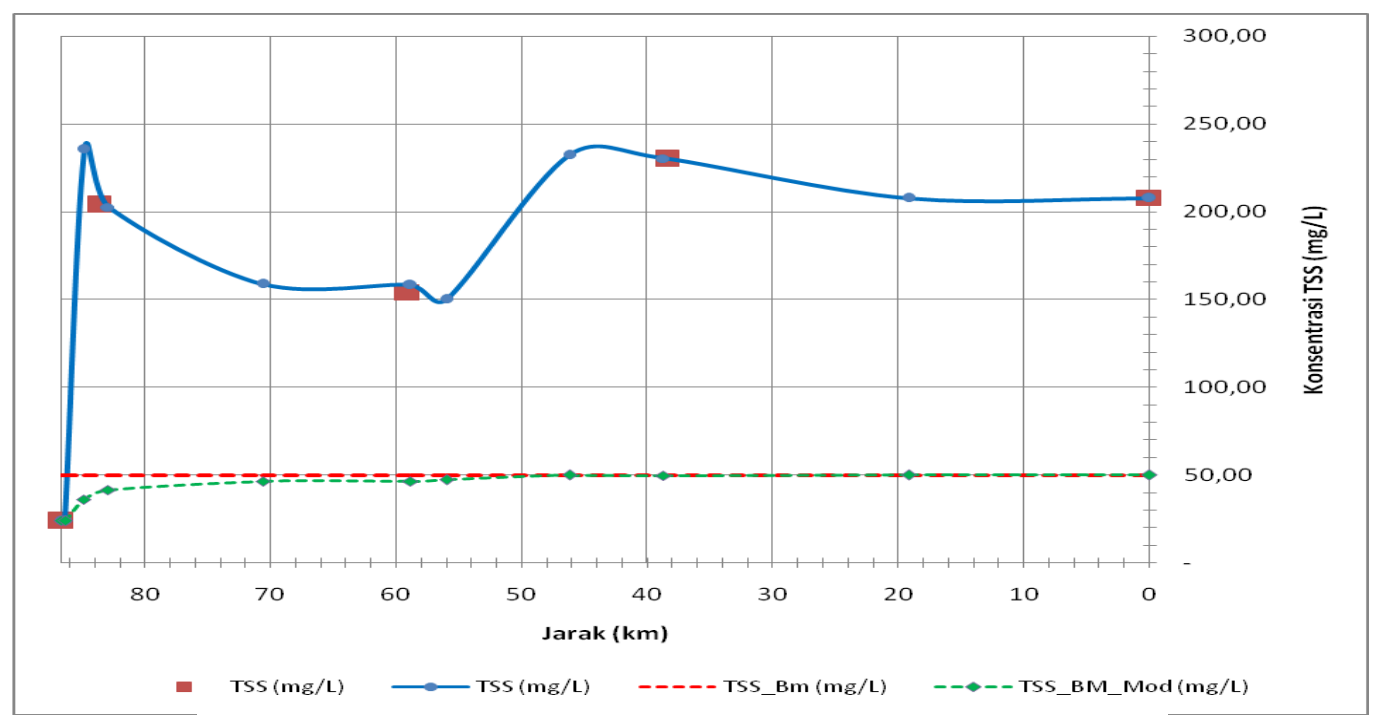

Gambar 5. Perbandingan Sebaran TSSmodel dengan TSSbakumutu

Gambar 5 memperlihatkan bahwa konsentrasi TSS di sungai utama rata-rata sudah cukup tinggi diatas baku mutu. Hal ini disebabkan karena tingginya konsentrasi TSS di hulu sungai utama serta adanya kenaikan konsentrasi TSS di kilometer 20 sampai 45 dan di kilometer 70 sampai kilometer 83,50. Kombinasi debit dan konsentrasi TSS pada sumber-sumber pencemar yang membentuk sebaran konsentrasi TSSbaku mutu digunakan sebagai dasar perhitungan daya tampung beban pencemaran TSS. Hasil perhitungan daya tampung beban pencemaran TSS disajikan pada Tabel 10. 
Tabel 10. Perhitungan Daya Tampung Beban Pencemaran TSS

\begin{tabular}{|c|c|c|c|c|c|c|c|c|}
\hline \multirow{3}{*}{ Sources } & \multicolumn{3}{|c|}{ Lokasi } & \multicolumn{2}{|c|}{ Debit } & TSS & \multirow{2}{*}{\multicolumn{2}{|c|}{ Daya Tampung TSS }} \\
\hline & \multirow{2}{*}{$\mathrm{km}$} & \multirow{2}{*}{$\begin{array}{l}\mathrm{Up} \\
\mathrm{km} \\
\end{array}$} & \multirow{2}{*}{$\begin{array}{c}\text { Down } \\
\mathrm{km} \\
\end{array}$} & \multirow{2}{*}{$\begin{array}{c}\text { Abstraction } \\
\mathrm{m} 3 / \mathrm{s} \\
\end{array}$} & \multirow{2}{*}{$\begin{array}{c}\text { Inflow } \\
\mathrm{m} 3 / \mathrm{s} \\
\end{array}$} & \multirow{2}{*}{$\mathrm{mg} / \mathrm{L}$} & & \\
\hline & & & & & & & Ton/Jam & $\mathrm{Kg} /$ Hari \\
\hline S. Singingi & 86,009 & & & & 14,28 & 50,00 & 2,57 & 61.689 \\
\hline S. Sitingkai & 82,09 & & & & 3,70 & 50,00 & 0,67 & 15.984 \\
\hline S. Lipai & 58,561 & & & & 5,38 & 50,00 & 0,97 & 23.242 \\
\hline S. Teso & 53,37 & & & & 19,09 & 50,00 & 3,44 & 82.471 \\
\hline S. Bunut (Wen) & 38,94 & & & & 0,60 & 50,00 & 0,11 & 2.592 \\
\hline NPS 1 & & 83,50 & 83,00 & & 2,00 & 120,00 & 0,86 & 20.736 \\
\hline NPS 2 & & 70,00 & 60,00 & & 2,00 & 150,00 & 1,08 & 25.920 \\
\hline NPS 3 & & 55,00 & 50,00 & & 2,00 & 97,00 & 0,70 & 16.762 \\
\hline NPS 4 & & 45,00 & 40,00 & & 2,00 & 100,00 & 0,72 & 17.280 \\
\hline NPS 5 & & 38,00 & 20,00 & & 2,00 & 93,00 & 0,67 & 16.070 \\
\hline NPS 6 & & 18,00 & 1,00 & & 2,00 & 93,00 & 0,67 & 16.070 \\
\hline Total DT TSS & & & & & & & 12,45 & 298.816 \\
\hline
\end{tabular}

Keterangan: $\quad$ NPS adalah sumber pencemar non titik dan

DT adalah Daya Tampung beban pencemaran.

Sumber: Data primer.

Total daya tampung beban pencemaran TSS sebesar 12,45 Ton/jam. Dengan kondisi seperti ini, maka beban pencemaran parameter TSS telah melampaui daya tampungnya sebesar 43,45 Ton/jam. Kondisi ini erat kaitannya dengan berbagai aktivitas masyarakat yang terdapat disepanjang sungai Kampar kiri seperti aktivitas penambangan emas tanpa izin (PETI) dan penambangan pasir sungai (galian C) yang banyak ditemukan di sepanjang daerah tersebut. Aktivitas PETI dilakukan dengan mengeruk atau menyedot sedimen di dasar sungai yang dapat menyebabkan meningkatnya kandungan TSS di perairan sungai. Disamping itu keberadaan perkebunan sawit dan perkebunan karet milik masyarakat juga sebagai sumber peningkatan konsentrasi TSS pada sungai Kampar Kiri, dimana pada musim penghujan dengan tingkat curah hujan yang cukup tinggi, akan membawa serta tanah lapisan bagian atas dari kebun masyarakat tersebut ke sungai sehingga sungai menjadi sangat keruh dengan warna kecoklatan serta menyebabkan terjadinya pencemaran pada air sungai.

\section{Pengelolaan Sumber Pencemar TSS}

Pengelolaan sumber-sumber pencemar TSS didasarkan pada selisih antara beban pencemaran (BP) dengan daya tampung (DT) seperti tersaji pada Tabel 11.

Tabel 11. Pengelolaan Sumber Pencemar TSS

\begin{tabular}{|c|c|c|c|c|c|}
\hline Sumber & Lokasi & & & Selisih & Keterangan \\
\hline Pencemar & $(\mathrm{Km})$ & DT & $\mathrm{BP}$ & Ton/jam & \\
\hline S. Singingi & 86,009 & 2,57 & 23,93 & $-21,36$ & Beban harus dikurangi89,26\% \\
\hline S. Sitingkai & 82,09 & 0,67 & 0,48 & 0,19 & Dapat menerima beban $39,58 \%$ \\
\hline S. Lipai & 58,561 & 0,97 & 2,40 & $-1,43$ & Beban harus dikurangi 59,58\% \\
\hline S. Teso & 53,37 & 3,44 & 32,54 & $-29,1$ & Beban harus dikurangi $89,43 \%$ \\
\hline $\begin{array}{c}\text { S.Bunut/We } \\
\mathrm{n}\end{array}$ & 38,94 & 0,11 & 0,08 & 0,03 & Dapat menerima beban $37,50 \%$ \\
\hline NPS 1 & $83,50-83,00$ & 0,86 & $-1,98$ & 2,84 & $\begin{array}{c}\text { Dapat menerima beban } \\
143,43 \%\end{array}$ \\
\hline NPS 2 & $70,00-60,00$ & 1,08 & $-1,44$ & 2,52 & $\begin{array}{c}\text { Dapat menerima beban } \\
175,00 \%\end{array}$ \\
\hline NPS 3 & $55,00-50,00$ & 0,70 & $-0,36$ & 1,06 & $\begin{array}{c}\text { Dapat menerima beban } \\
294.44 \%\end{array}$ \\
\hline NPS 4 & $45,00-40,00$ & 0,72 & 0,07 & 0,65 & $\begin{array}{c}\text { Dapat menerima beban } \\
928.57 \%\end{array}$ \\
\hline NPS 5 & $38,00-20,00$ & 0,67 & 0,11 & 0,56 & $\begin{array}{l}\text { Dapat menerima beban } \\
509,09 \%\end{array}$ \\
\hline NPS 6 & $18,00-1,00$ & 0,67 & 0,07 & 0,60 & $\begin{array}{c}\text { Dapat menerima beban } \\
857,14 \% \\
\text { Beban harus dikurangi } 77,73 \%\end{array}$ \\
\hline
\end{tabular}


DT adalah Daya Tampung beban pencemaran.

Sumber: Data primer.

BP adalah beban pencemaran

Dari tabel diatas, terlihat beban pencemaran parameter TSS beberapa anak sungai yang masuk ke sungai utama masih lebih tinggi dari daya tampungnya. Daya tampung beban pencemar TSS anak Sungai Singingi telah terlampaui $89,26 \%$ atau sebesar 21,3 Ton/jam, demikian juga daya tampung beban pencemar TSS anak Sungai Lipai telah terlampaui 59,58\% atau sebesar 1,43 Ton/jam dan daya tampung beban pencemar TSS anak Sungai Teso telah terlampaui 89,43\% atau sebesar 29,1 Ton/jam. Terjadinya lonjakan konsentrasi TSS di anak Sungai Singingi, anak sungai Sitingkai dan anak Sungai Teso kemungkinan erat kaitannya dengan aktivitas penambangan emas tanpa izin (PETI) dan penambangan pasir sungai (galian C) serta perkebunan masyarakat yang banyak ditemukan di sepanjang daerah tersebut. Sementara beberapa anak sungai lainnya seperti anak Sungai Sitingkai dan anak Sungai Bunut (Wen) serta semua sumber-sumber pencemar non titik (NPS), dari NPS1 hingga NPS6 masih dapat menerima beban TSS karena konsentrasi TSS-nya masih berada di bawah baku mutu.

\section{Identifikasi Lokasi Sumber Pencemar}

Berdasarkan uraian beban pencemaran dan daya tamping BOD, COD dan TSS diatas, dapat diidentifikasi sumber-sumber pencemar yang perlu mendapat perhatian lebih lanjut. Rangkuman sumbersumber pencemar yang perlu mendapat perhatian khusus disajikan pada Tabel 12. Berdasarkan Tabel 12, anak Sungai Singingi serta anak Sungai Teso yang masuk ke Sungai Kampar Kiri pada kilometer ke 86,009 dan kilometer ke 53,37 merupakan anak-anak sungai yang mempunyai kelebihan beban pencemar yang cukup signifikan sehingga menyebabkan konsentrasi parameter pencemar BOD, COD serta TSS di sungai utama melewati baku mutu air kelas I.

Tabel 12. Lokasi Sumber Pencemar yang Kelebihan Beban

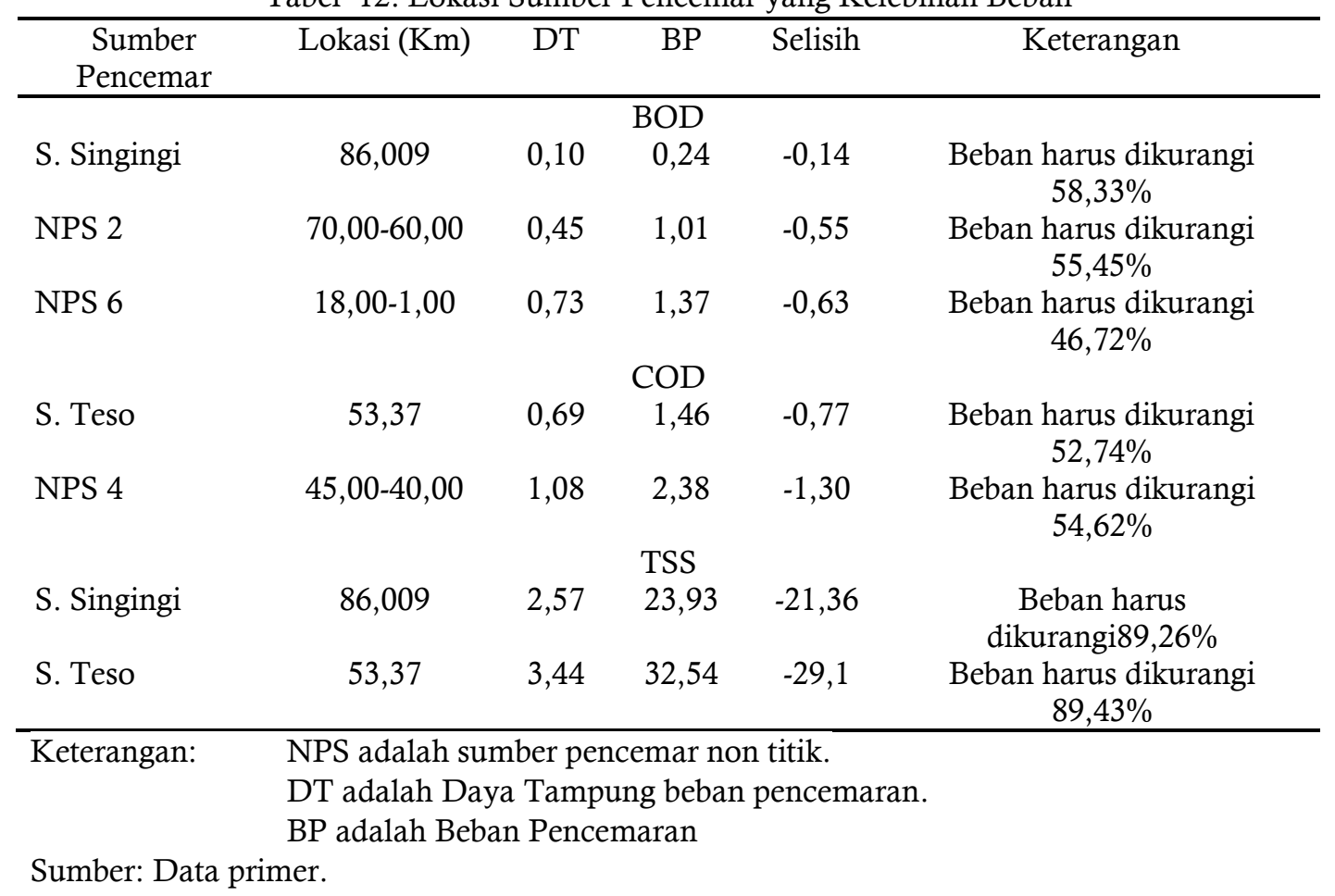

\section{Sosial Ekonomi Masyarakat sekitar Sungai Kampar Kiri}

Kabupaten Kampar mempunyai banyak potensi yang masih dapat dimanfaatkan, terutama di bidang perkebunan dan perikanan darat. Sebagian besar penduduk bekerja di sektor perikanan, perkebunan, dan kehutanan. Bidang perkebunan seperti kelapa sawit dan karet yang merupakan salah satu tanaman yang sangat cocok pada lahan yang ada di Kabupaten Kampar. Di bidang perikanan, budidaya ikan yang dikembangkan menggunakan keramba (kolam ikan berupa rakit) di sepanjang sungai kampar, ini terlihat banyaknya keramba yang berjejer rapi di sepanjang sungai dan anak sungai Kampar kiri yang merupakan milik masyarakat atau milik pemerintah yang bekerja sama dengan pihak swasta. Hasil pengamatan terhadap sosial ekonomi masyarakat dalam pemanfaatan sungai Kampar Kiri untuk kegiatan perikanan memiliki dampak positif, yaitu dapat meningkatkan pendapatan masyarakat. Jenis ikan yang 
dibudidaya antara lain : ikan patin, ikan baung, ikan tapah dan ikan nila yang merupakan komoditas yang memiliki pangsa pasar yang cukup baik di Propinsi Riau, Padang, Jambi dan Sumatera Utara.

Dari kegiatan budidaya ikan menggunakan keramba disepanjang sungai tersebut, selain memberikan dampak positif juga dapat memberikan dampak negatif berupa penurunan kualitas air sungai akibat pemberian pakan yang tidak mengikuti kaidah budidaya ikan yang baik. Pembesaran ikan yang dilakukan dengan cara memberikan limbah ayam mati (usus / jeroan ayam) dalam jumlah yang banyak. Limbah organik ini dapat meningkatkan jumlah BOD di dalam air sungai karena terjadi penumpukan limbah organik dalam jangka waktu yang lama.

Peningkatan beban pencemaran parameter BOD juga disebabkan oleh buangan limbah dari kegiatan rumah tangga penduduk, aktifitas pertanian dan perkebunan. Penurunan kualitas air sungai berdampak negatif terhadap budidaya ikan seperti terjadinya wabah penyakit pada ikan patin, baung, tapa, nila yang dibudidaya. Ikan yang terkena penyakit biasanya memiliki borok, sirip geripis, perut kembung dan lain-lain dimana secara estetika tidak enak dipandang serta timbul rasa enggan untuk membeli dan mengkonsumsinya sehingga menyebabkan menurunnya hasil penjualan ikan.

Secara kontekstual seharusnya keberadaan perusahaan HTI (Hutan Tanaman Industri) yang cukup besar di kabupaten Kampar, dapat membantu meningkatkan perekonomian dan kondisi sosial masyarakat disekitar areal HTI atau di sekitar areal pembibitan tanamannya (nursery) mereka khususnya yang berada di kecamatan Kampar Kiri, karena perusahaan HTI cukup berpengaruh terhadap memperluas kesempatan bekerja sehingga dapat meningkatkan pendapatan bagi masyarakat yang bekerja di perusahaan tersebut. Namun hal ini tidak berpengaruh terhadap masyarakat yang berprofesi sebagai petani, pekebun ataupun nelayan. Sejauh ini keberadaan industri kehutanan tersebut cenderung menimbulkan pengaruh negatif yang ditunjukkan dengan terjadinya perusakan hutan alam secara besar-besaran, pembalakan liar (illegal loging), perampasan lahan milik masyarakat adat dan memicu terjadinya kebakaran hutan (Risa Anjasari, 2009).

Disamping itu dari hasil penelitian ini pada beberapa penggal Sungai Kampar Kiri konsentrasi beban pencemar COD meningkat yang di perkirakan berasal dari penggunaan pupuk dan pestisida pada areal perkebunan atau pun lokasi pembibitan tanaman industri. Peningkatan konsentrasi beban pencemar COD ini akan berakibat penurunan kualitas air yang pada akhirnya akan mengurangi tangkapan masyarakat yang berprofesi sebagai nelayan. Pada dasarnya pembangunan HTI atau pun perkebunan lainnya mempunyai 3 sasaran utama yang dapat dicapai yakni sasaran ekonomi, ekologi dan sosial (Iskandar, 2005). Oleh karena itu dalam mewujudkan pembangunan HTI, adanya peran dan partisipatif dari masyarakat sekitar, baik dalam memberikan dukungan material maupun non material serta bekerjasama dengan pihak lainnya dapat memperlancar dan mempercepat pelaksanaan pembangunan HTI serta akan memberikan berdampak positif yang lebih besar terhadap segi sosial maupun ekonomi masyarakat sekitar.

Selain bidang pertanian tanaman pangan dan bidang perkebunan, bidang pertambangan dan jasa saat ini telah menjadi jenis mata pencaharian yang banyak dilakukan oleh masyarakat disekitar Sungai Kampar Kiri, khususnya pada Sungai Singingi. Sementara pada hulunya Sungai Singingi juga terdapat pabrik sawit dan pabrik sagu masyarakat serta perkebunan sawit, karet dan pisang milik masyarakat. Dengan tingkat pendidikan masyarakat sekitar yang masih tergolong rendah, maka aktivitas masyarakat sekitar sungai seperti pemanfaatan sungai sebagai untuk mandi, mencuci dan sebagai kakus (MCK), sebagai tempat pembuangan sampah dan limbah cair rumah tangga/ rumah makan, akan lebih banyak berpotensi negatif terhadap kualitas air sungai Kampar Kiri.

Kontribusi pencemaran lainnya terhadap kualitas air sungai ditimbulkan dari kegiatan pertambangan emas tanpa izin (PETI) serta pertambangan bahan galian C milik masyarakat di beberapa ruas sungai yang meningkatkan konsentrasi beban pencemar TSS serta berakibat keruhnya air sungai serta turunnya kandungan Oksigen dalam air, yang pada akhirnya mengakibatkan turunnya kualitas serta estetika air sungai Kampar Kiri. Peran pemerintah dalam penataan pemukiman sekitar sungai, program pengadaan MCK komunal serta program pemberdayaan masyarakat dalam sanitasi lingkungan serta sosialisasi penerapan peraturan pengelolaan kegiatan yang berwawasan lingkungan terhadap masyarakat sekitar sungai yang dilakukan secara terprogram dan berkelanjutan.

\section{KESIMPULAN}

Total beban pencemaran BOD di sungai utama di daerah penelitian sebesar 4,83 Ton/jam dan total daya tampung beban pencemaran BOD sebesar 2,65 Ton/jam. Itu berarti daya tampung beban pencemaran BOD pada sungai utama sudah terlampaui dan beban pencemaran BOD harus dikurangi sebesar 2,18 Ton/jam. Total beban pencemaran COD sebesar 8,16 Ton/jam sementara total daya tampung 
beban pencemaran COD sebesar 8,45 Ton/jam. Ini berarti bahwa sungai utama masih dapat menerima tambahan beban COD sebesar 0,29 Ton/jam. Total beban pencemaran TSS sebesar 55,90 Ton/jam sementara itu daya tampung beban pencemaran TSS hanya sebesar $12,45 \mathrm{Ton} / \mathrm{jam}$. Sungai utama harus dikurangi beban pencemaran TSS sebesar 43,45 Ton/jam. Sumber pencemar BOD yang penting di daerah penelitian berasal dari anak sungai Singingi yang masuk ke Sungai Kampar Kiri pada kilometer ke 86 sebesar 0,24 Ton/jam, serta dari sumber pencemar non titik pada kilometer 60 sampai kilometer 70 (NPS2) sebesar 1,01 Ton/jam dan dari NPS6 (kilometer 1 sampai 18) sebesar 1,37 Ton/jam. Sumber pencemar titik parameter COD berasal dari anak sungai Teso yaitu sebesar 1,46 Ton/jam, sedangkan dari sumber pencemar non titik teridentifikasi di sekitar kilometer 40 hingga kilometer 45 (NPS4) dan di sekitar kilometer 1 hingga kilometer 18 (NPS6) masing-masing sebesar 2,38 Ton/jam. Sementara itu penyebab tingginya konsentrasi TSS terutama berasal dari aktivitas penambangan emas tanpa izin (PETI) serta penambangan pasir (galian C) yang terdapat di hampir sepanjang sugai Kampar Kiri (sungai utama) serta anak sungai Singingi $(23,93 \mathrm{Ton} / \mathrm{jam})$ dan anak sungai Teso (32,54 Ton/jam).

\section{UCAPAN TERIMAKASIH}

Penulis menyampaikan terimakasih kepada seluruh pihak yang membantu dalam kelancaran penelitian ini.

\section{DAFTAR PUSTAKA}

[FWI] Forest Watch Indonesia.2015.Pelanggaran Perusahaan Hutan Tanaman Industri (HTI) dan Pembiayaan "Studi Kasus PT. Toba Pulp Lestari dan APRIL Group": Bogor Indonesia

Iskandar. 2005. Panduan Pelatihan Pengelolaan Kualitas Air. Puslitbang Sumberdaya Air Kementerian Pekerjaan Umum. Jakarta.

Risa Anjasari, 2009..Pengaruh Hutan Tanaman Industri (HTI) Terhadap Kondisi Sosial Ekonomi Masyarakat Di Kecamatan Kampar Kiri.Jurusan Perencanaan Wilayah Dan Kota Fakultas Teknik Universitas Diponegoro Semarang: Page 1-3 